\title{
Primary malignant mesenchymoma of bone
}

\section{A case report}

\author{
Errol U.Hutagalung ${ }^{*}$, Saukani Gumay ${ }^{* *}$, Bambang Budiatmoko ${ }^{* * *}$, Suga Anggawidjaja**
}

\begin{abstract}
Abstrak
"Primary malignant mesenchymoma of bone"(PMMB) merupakan tumor ganas tulang yang sangat jarang didapat, dibentuk oleh dua atau lebih komponen mesenkimal ganas yang tidak saling berhubungan, selain fibrosarkoma atau malignant fibrous histiocytoma. Penelusuran kepustakaan hanya menghasilkan sebanyak 16 laporan kasus yang hampir semuanya terdiri dari osteosarkoma dan liposarkoma. Kami melaporkan satu kasus PMMB yang dibentuk oleh liposarkoma, rabdomiosarkoma, dan kondrosarkoma derajat tinggi di distal femur kiri pada seorang penderita laki-laki berusia 52 tahun, yang mengakibatkan kematian penderita dalam 3 bulan setelah perawatan. (Med J Indones 2001; 10: 235-41)
\end{abstract}

\begin{abstract}
Primary malignant mesenchymoma of bone (PMMB) is an exceedingly rare neoplasm consisting of two or more unrelated malignant mesenchymal components other than fibrosarcoma or malignant fibrous histiocytoma. Review of the literature reports only 16 cases, most of which were composed of osteosarcoma and liposarcoma. We report a case of PMMB composed of liposarcoma, rhabdomyosarcoma and high grade chondrosarcoma arising within the left distal femur in a 52-year-old male, resulting in the patient's death 3 months after presentation. (Med J Indones 2001; 10: 235-41)
\end{abstract}

Keywords: Bone tumor-malignancy, liposarcoma, dedifferentiated chondrosarcoma, rhabdomyosarcoma

Malignant mesenchymoma is a malignant lesion characterized by the presence of two or more distinct mesenchymal lines of differentiation exclusive of a fibroblastic line of differentiation. Most cases of malignant mesenchymoma that have been reported were derived from the soft tissue, while primary malignant mesenchymoma of bone (PMMB) is a very rare neoplasm. ${ }^{14}$ Primary malignant mesenchymoma of bone (PMMB) is a neoplasm consisting of two or more unrelated malignant mesenchymal components other than fibrosarcoma or malignant fibrous histiocytoma.

The first case of PMMB was reported by Lichtenstein in $1952 .{ }^{5}$ Since then only 15 additional cases have

\footnotetext{
* Division of Orthopaedic Surgery, Faculty of Medicine, University of Indonesia / Dr Cipto Mangunkusumo

General Hospital, Jakarta, Indonesia

** Department of Patologic Anatomy, Faculty of Medicine, University of Indonesia / Dr Cipto Mangunkusumo General Hospital, Jakarta, Indonesia

*** Department of Radiology, Faculty of Medicine, University of Indonesia / Dr Cipto Mangunkusumo General Hospital, Jakarta, Indonesia
}

been reported in the literature. ${ }^{6,7}$ The last case reported was in 1997 by Van Dorpe et al. ${ }^{6}$ Search of the literature from 1998 until present time in electronic format did not reveal additional cases. All of the reported cases contained an osteosarcoma component. ${ }^{6,7}$

We report an exceedingly rare case of PMMB composed of a high grade chondrosarcoma, liposarcoma and rhabdomyosarcoma in a 52-year-old male arising in the distal left femur.

To our knowledge this is the first case reported from Indonesia and also the first case of PMMB that did not contain an osteosarcomatous component.

\section{CASE REPOR'T}

A 52-year-old male was admitted to the Dr. Cipto Mangunkusumo National Central General Hospital. He complained of pain in the left thigh for about one year. In the last two months the left femur became swollen gradually. 
On physical examination the patient was in good condition. He had a firm mass on the distal left femur, measuring about $10 \times 10 \times 5 \mathrm{~cm}$. The tumor seemed attached to the underlying bone, poorly circumscribed and painful. The flexion of the left knee was limited.

Laboratory studies showed only an increased ESR. Plain radiographs of the distal left femur showed a geographic pattern with lytic and sclerotic areas, and irregular borders, involving the metaphysis and diaphysis. The cortex was thickened. There was no obvious periosteal reaction. Chest X-ray showed no evidence of a specific process or pulmonary metastases.

Based on clinical and radiological information a provisional diagnosis of a neoplastic disease with differential diagnosis of chronic infection of the bone was made, and an open incisional biopsy was performed. Materials taken from the bone and affected soft tissue were acquired for histopathological examination.

\section{Pathologic findings}

Grossly, the specimen consisted of multiple fragments of soft tissue (about $10 \mathrm{ml}$ ) and fragmented bone (about $15 \mathrm{ml}$ ).

Microscopically: On $\mathrm{H} \& \mathrm{E}$ staining, the soft tissue specimens consisted of tumor cells with a myxoid matrix. The cells were round, oval, and some were spindle shaped, with pleomorphic and hyperchromatic nuclei, some of which were eccentric. Mitotic figures could be found. The bone specimens showed a similar picture, but besides there was also a chondroblastic tumor which was hypercellular, with lobulated, binucleated, plump nuclei, and some mitoses in a hyaline or myxoid matrix. There were also foci of calcification and necrosis. Conclusion: consistent with chondrosarcoma grade 2- 3 (high grade).

Based on the diagnosis of chondrosarcoma grade 2-3, a further work up was done. CT scan showed that there was an intramedullary mass with cortical destruction without periosteal reaction. The tumor extended to the soft tissue through the cortical destruction, mostly to the posterior side of the femur. After a thorough preoperative evaluation, it was decided that a limb salvage operation was feasible. The patient then underwent a limb salvage procedure, in which the distal part of femur inclusive the affected soft tissue was resected. To reconstruct the defect an osteoarticular allograft was inserted and fixed with plate and screw. Reconstruction for achieving knee stability was done as necessary. The resected part was sent to pathological department for examination.

Histopathological findings of the resected part :

Grossly: the resected part showed a part of femoral bone measuring about $28 \mathrm{~cm}$ long with a soft tissue mass attached to the bone. The soft tissue measured about $10.0 \times 8.0 \times 6.0 \mathrm{~cm}$. On cross section, the bone showed an intramedullary mass.

Microscopically: H \& E staining showed similar findings with the biopsy specimen, but in this specimen besides the high grade chondrosarcomatous component, there were also lipoblasts, giant cells, tadpole cells, spiderweb cells and bizarre cells. These findings were in accordance with a liposarcoma and a rhabdomyosarcoma. Based on these microscopic findings, the final diagnosis was a PMMB, consisting of a liposarcoma, rhabdomyosarcoma and a high grade chondrosarcoma. The post operative course was uneventful. The patient was released 14 days postoperatively.

Six weeks after the surgery or 3 months after admission, at home the patient suddenly developed a respiratory distress. He was immediately brought to a nearest hospital. Chest X-ray showed a snow storm appearance of both lungs due to metastatic process. The patient died on the same day. An autopsy was not performed.

\section{DISCUSSION}

Primary malignant mesenchymoma of bone is very rare. Review of the literature until 1997 revealed only 16 cases. ${ }^{6,7}$ Search in electronic format did not reveal additional cases. Schajowicz ${ }^{8}$ reported a tumor in bone that predominantly showed liposarcomatous elements with focal areas of osteogenic sarcoma. Osteoliposarcoma of bone was then suggested as a name for this tumor; it specified the most common main cellular components of the mesenchymal tumor. Review of the literature demonstrated that the tumor could occur in any age, with an age range of 12 to 69 years. ${ }^{6,7}$ An osteosarcomatous component was present in all sixteen reported cases and a liposarcomatous component was present in 10 cases, so that the name osteoliposarcoma is justified. ${ }^{6,7}$ 
Malignant mesenchymoma has been accepted by Lichtenstein ${ }^{4}$ as a distinct entity and was included in his classification. Although the combination of liposarcomatous and osteosarcomatous components is the most common finding in malignant mesenchymoma, but other combinations of malignant tissue of mesenchymal origin have been encountered too. ${ }^{5-10}$

Approximately two-thirds of the reported cases arose in the metaphysis of a long tubular bone, ${ }^{5,6,8-10}$ as happened in our case; it arose in the metaphyseal part of the distal left femur. The lung was the most common site of metastatic involvement. In more than a half of the followed-up cases, the prognosis was poor, with death occurring within two years, ${ }^{7,9,10}$ as happened in our case.

The histogenesis of PMMB, like that of malignant mesenchymoma of soft tissue, remains obscure. Aberrant gene expression or inhibition might play a role. ${ }^{6}$ This tumor may arise from a primitive mesenchymal cell with the ability to differentiate into various components, or the neoplasm may contain multiple clones from which the various components are derived. ${ }^{\text {? }}$

PMMB has similar characteristics with dedifferentiated chondrosarcoma (chondrosarcoma with additional mesenchymal components). Dedifferentiated chondrosarcoma consists of a well-differentiated (low-grade) chondrosarcoma and a high-grade nonchondroid sarcoma such as malignant fibrous histiocytoma, fibrosarcoma, osteosarcoma, angiosarcoma or rhabdomyosarcoma. ${ }^{3,6,7,11}$ The dedifferentiated chondrosarcoma arises predominantly in the pelvis and lower extremities, presents between sixth and seventh decades of life and has a male-preponderance. ${ }^{6,7,9}$ The junction of cartilaginous and noncartilaginous elements in dedifferentiated chondrosarcoma is usually discrete, without a zone of gradual transition. Radiographs will often have radiographic evidence of a discrete, preexistent cartilaginous component. The prognosis of dedifferentiated chondrosarcoma, like that of primary malignant mesenchymoma of bone, is poor with a survival of less than 2 years. ${ }^{7}$

The tumor presented in this case report is composed of three distinct differentiated malignant mesenchymal components (rhabdomyosarcoma, high grade chondrosarcoma, and liposarcoma) arising within the distal left femur. The chondrosarcomatous component is high grade, so that our case is not a dedifferentiated chondrosarcoma. The case of PMMB with rhabdomyo- sarcomatous, chondrosarcomatous, and liposarcomatous tissues without an osteosarcomatous component have not been reported. In our case the rhabdomyosarcomatous and chondrosarcomatous elements were the most prominent, while the liposarcomatous element was the least. All of the reported cases contained an osteosarcomatous component, but in this case no osteosarcomatous component was found. This is the first case of PMMB that did not contain an osteosarcomatous component.

The initial diagnosis in our case was chondrosarcoma grade $2-3$, because the result of histopathological examination of limited tissue obtained by incisional biopsy revealed only a chondrosarcomatous component. Histopathological examination of the whole resected tissue showed additional liposarcomatous and rhabdomyosarcomatous components; thus making the final diagnosis as a PMMB.

Finding of only one kind of malignancy in the biopsy specimen, was also experienced by Scheele et al, ${ }^{7}$ Schajowics et al, ${ }^{8}$ Reijnierse et $\mathrm{al}^{9}$ and Ross et al. ${ }^{10}$ In their cases, diagnosis of PMMB were obtained after a definitive treatment such as resection ${ }^{7}$ and amputation. ${ }^{8-10}$ The recommended treatment was operative removal of the tumor followed by chemotherapy or radiotherapy. ${ }^{9}$ Prognosis was universally grim, regardless of the therapy; neither radiotherapy nor chemotherapy given after operation gave satisfactory result; metastasis and death most often occurred within two years. ${ }^{7,9,10}$ The case of Scheele et al. ${ }^{7}$ died 4 months after initial presentation, while the case of Ross et al. ${ }^{10}$ died 5 months after diagnosis. In our case, the patient had a limb salvage procedure, because the initial diagnosis after biopsy was chondrosarcoma. In this operation, the affected bone was resected and the defect was reconstructed with a massive osteoarticular allograft. Allograft has been used to reconstruct defects after tumor resection. ${ }^{12}$ An allograft is a tissue that is transferred between two genetically different individuals of the same species. ${ }^{13}$ Allografts were primarily used for massive grafting procedures in which an autograft was not an alternative, ${ }^{14}$ Our case succumbed 3 months after admission, due to acute respiratory distress caused by multiple metastases in both lungs showing a snowstorm appearance.

In conclusion, a case of a very rare neoplasm of bone composed of rhabdomyosarcoma, chondrosarcoma, and liposarcoma, that is best classified as a PMMB is reported. Review of the literature revealed that this is the first case reported from Indonesia and also the 
first case of PMMB that did not contain an osteosarcomatous component.

To minimize the risk of difference between the diagnosis of biopsy specimen and of a larger specimen obtained at definitive surgery, we suggested that diagnosis of a malignancy of the bone should be discussed in depth by the three pillars of specialty that are involved in the management of bone tumors as a team: Orthopaedic surgeon, Radiologist and Pathologist. The above mentioned effort had been routinely performed by our team since 1995 in a Clinico Pathological Conference (C.P.C.). Thus the C.P.C. should be a standard procedure in the management of bone tumors.

\section{REFERENCES}

1. Weiss SW. Histological typing of soft tissue tumors. In: Sobin LH, ed. International histological classification of tumours. $2^{\text {nd }}$ ed. Berlin: Springer; 1994. p.46.

2. Schajowicz F. Histological typing of bone tumors. In: Sobin LH, ed. International histological classification of tumour. $2^{\text {nd }}$ ed. Berlin: Springer; 1994.p.33.

3. Fechner RE, Mills SE. Tumors of the bones and joints. In: Rosai I, ed. Atlas of tumor pathology. $3^{\text {rd }}$ series, fase 8 .
Washington DC: Armed Forces Institute of Pathology; 1993.p.207-9

4. Lichtenstein L. Bone tumors. $5^{\text {th }}$ ed. St.Louis: Mosby; 1977.

5. Lichtenstein L. Bone Tumors. St Louis: Mosby; 1952.

6. Van Dorpe J, Sciot R, Samson I, De Vos R, Brys P, Van Damme B. Primary osteorhabdomyosarcoma (malignant mesenchymoma) of bone: a case report and review of the literature. Mod Pathol 1997; 10: 1047-53.

7. Scheele PM Jr, Von Kuster LC, Krivchenia G II. Primary malignant mesenchymoma of bone. Arch Pathol Lab Med 1990; 114: 614-7.

8. Schajowicz F, Cuevillas AR, Silberman FS. Primary malignant mesenchymoma of bone: a new tumor entity. Cancer 1966; 19: 1423-8.

9. Reijnierse M, Kroon HM, van der Heul RO, Mulder JD. Mesenchymoma of bone: a case report. J Bone Joint Surg (Am) 1993 ; 75-A: 112-5.

10. Ross CF, Hadfield G. Primary osteo-liposarcoma of bone (malignant mesenchymoma): report of a case. J Bone Joint Surg 1968 (Br);50-B: 639-43.

11. Aigner $T$, Dertinger $S$, Neureiter D, Kirchner T. Dedifferentiated chondrosarcoma is not a "de-differentiated" chondrosarcoma. Histopathology 1998; 33: 11-9.

12. Hornicek FJ, Gebhardt MC, Sorger JI, Mankin HJ, Bone graft substitutes: clinical application. Orthop Clin North Am 1999;30: 674-85.

13. Stevenson S. Autograft/allograft: biology of bone grafts. Orthop Clin North Am 1999; 30: 544-52.

14. Boyce T, Edwards J, Scarborough N. Autograft/allograft: allograft bone. Orthop Clin North Am 1999; 30: 572-82. 


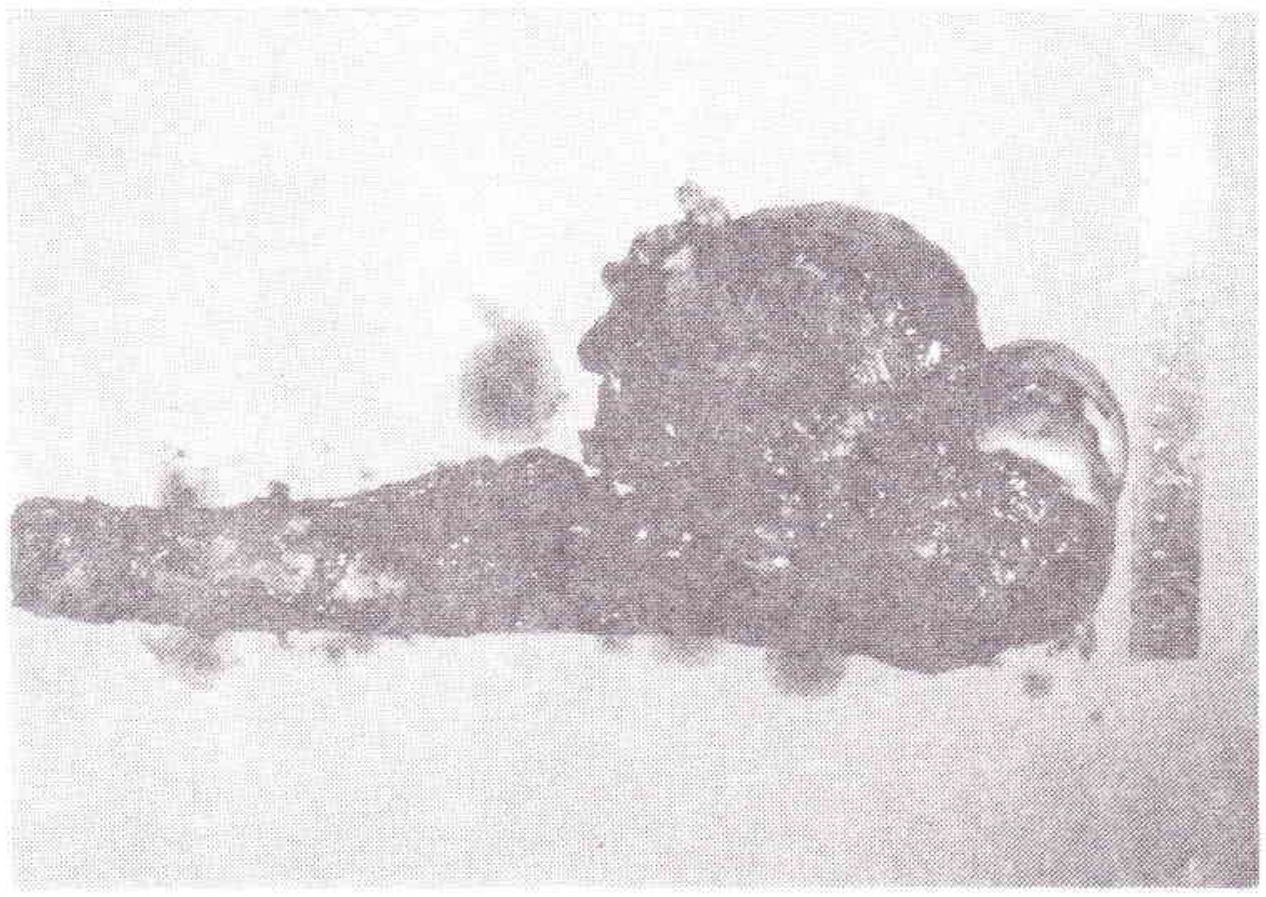

Figure 1. Photograph of the specimen showed the resected part consisted of the affected bone and attached pathologic soft tissue mass

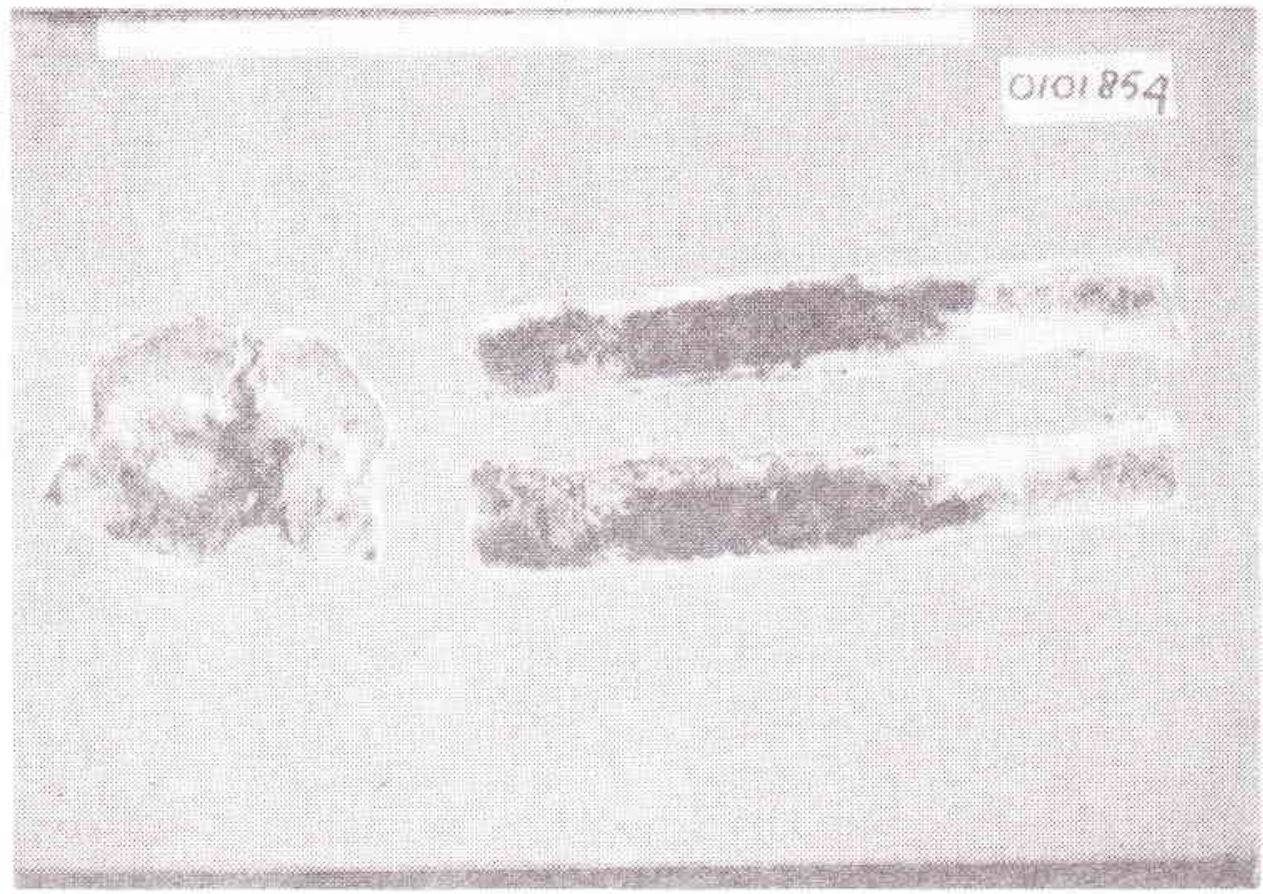

Figure 2. The resecied pan afier fixation in formalin showed intraneduliary mass and destruction of bone 


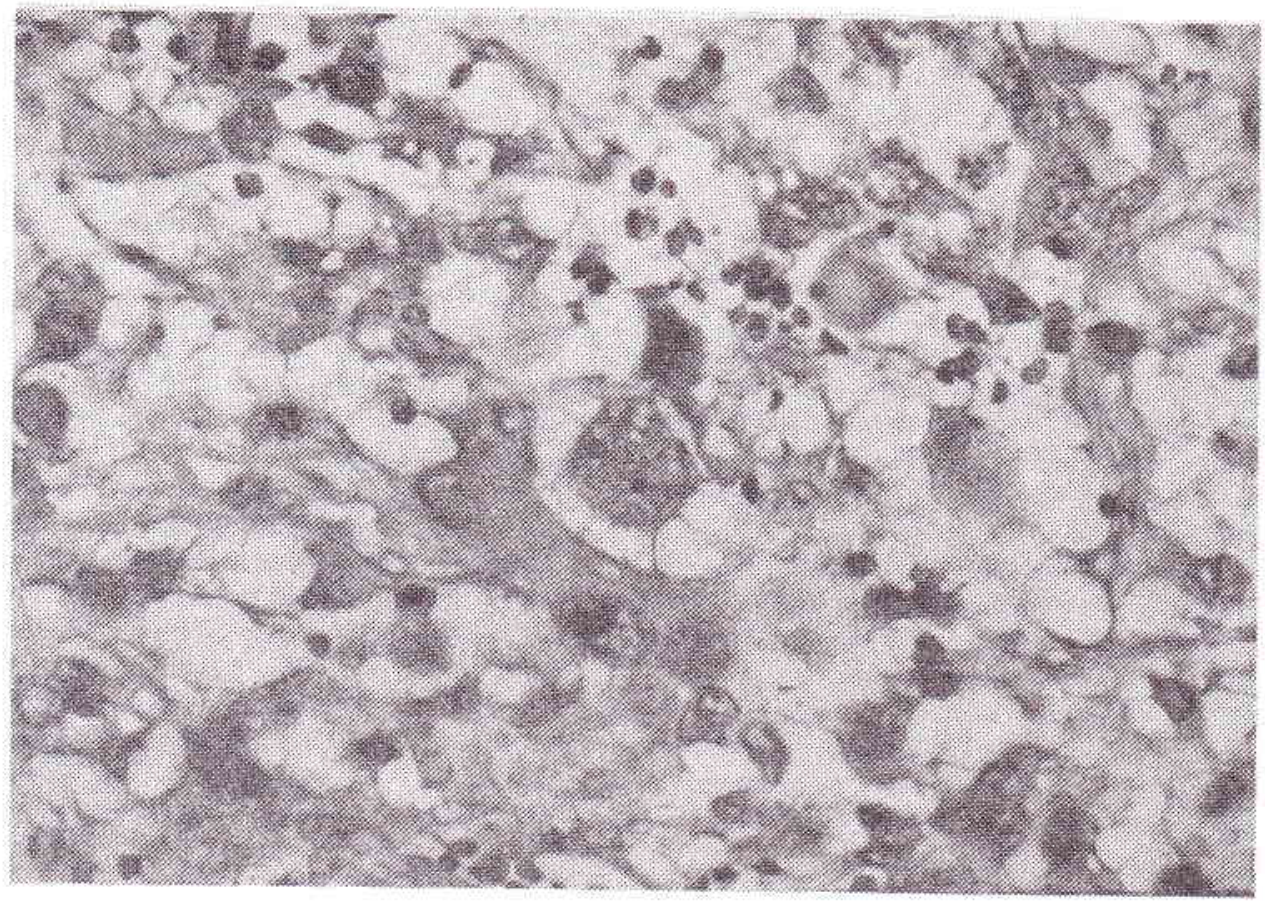

Figure 5. Liposarcomatous component showed lipoblast cells (hematoxyllin-eosin, x 528) 